\title{
The Intrathecal Infusion of Mesenchymal Stem Cells into Healthy Rabbits is Safe and Devoid of Neurological or Clinical Complications
}

\author{
Minguell $\mathrm{JJ}^{1 *}$, Pereira $\mathrm{A}^{1}$, Bartholomew $\mathrm{P}^{2}$ and Lasala GP1
}

${ }^{1}$ TCA Cellular Therapy, LLC. Covington, LA 70433 USA

${ }^{2}$ Pathology Department, Lakeview Regional Medical Center, Covington, LA, 70433 USA

\begin{abstract}
Background: Cellular, molecular and transplantation studies using mouse and rat models of neurological diseases have revealed that Mesenchymal Stem Cells (MSC) represent a reliable candidate for cellular therapies for neurological conditions, including Amyotrophic Lateral Sclerosis (ALS) and Spinal Cord Injury (SCI). However, evaluation of safety aspects associated with route and dose of cell infusion, pivotal issues in cell therapy, has not been tested in large animals.

Methods: This study was performed to evaluate whether the intrathecal infusion, by lumbar puncture (LP), of ex vivo-expanded MSC to healthy rabbits is a safe and feasible procedure. After infusion of the cell or placebo solution, clinical, neurological, behavioral and histopathological assessments were performed during five weeks. At the end of the follow up period, animals were sacrificed, autopsied and tissues prepared for histological examination.

Results and Conclusions: The results of this preclinical study showed that the intrathecal infusion of MSC can be readily performed under safe and feasible conditions. These findings and the observation that procedural security is independent of cell dose $\left(0.3-0.6 \times 10^{6} \mathrm{cells} / \mathrm{kg}\right.$ rabbit body weight), give additional safety support to the notion that ex vivo expanded MSC can be employed in clinical settings intended to treat neurological patients
\end{abstract}

Keywords: Mesenchymal stem cells; Intrathecal infusion; Preclinical study; Neurological cell therapy; Stem cells delivery

\section{Introduction}

A growing interest in the use of adult stem cells for the treatment of several neurological disorders has been developed over the last few years. This is the result of a better understanding of stem cell properties as well as encouraging conclusions from studies in neurologicaldamaged animals after treatment with stem cells [1-3].

The appealing molecular and cellular properties of Mesenchymal Stem Cells (MSC), a type of adult stem cells [4,5], have prompted the concept that these cells represent a reliable candidate for cell therapy for neurological diseases [6-8]. The above assertion is supported by three major facts: a) MSC can differentiate outside the mesenchymal lineage into neurological precursors $[5,9,10], \mathrm{b})$ after infusion of MSC to animals with genetic or experimental neurological diseases, MSC migrate and survive within the central nervous system $[6,11]$ and contribute to the improvement/recovery of pre-symptomatic motor functions [6,7,11-13] and c) MSC secrete several growth factors and chemokines that may create a neuroprotective environment favorable for tissue sparing and axonal regeneration [14,15 ].

A salient issue in cell therapy is the choice of a proper and safe route of administration of the cell product. Numerous studies have been performed to evaluate neuroplasticity, but not safety, after infusion (intravenous, intrathecal, subarachnoidal space or cortex) of MSC to mice models of motor neuron diseases [13,16-19]. In turn, intrathecal infusion $[12,20]$ emerges as an attractive option for cell delivery to treat neurological patients. However, there are no feasible data to assert that the intrathecal infusion of MSC to humans is safe and devoid of any serious neurotoxicity.

This study was performed to evaluate, prior the initiation of a clinical trial using MSC [21], whether the intrathecal infusion of MSC to healthy rabbits is feasible, safe and devoid of neurological damage. As compared to mice, rabbits which are phylogenetically, anatomical and physiological closer to humans, are also large enough for monitoring and evaluating physiological changes after an injury.

\section{Materials and Methods}

\section{Animals}

Male New Zealand white normal rabbits (12 weeks, 2.7-3.2 kg body weight, Harlan Laboratories, www.harlan.com) were used for bone marrow aspiration and for intrathecal MSC infusion. Rabbits were kept in cages and received food and water without restrictions. All animal studies were done in accordance with the National Institutes of Health Guidelines for the care and use of mammals in Neuroscience and Behavioral Research (http://grants.nih.gov/grants/olaw/National_ Academies_Guidelines_for_Use_and_Care.pdf).

\section{Bone marrow procurement}

Animals were anesthetized (IM administration of ketamine (25 $\mathrm{mg} / \mathrm{kg})$ and xylazine $(10 \mathrm{mg} / \mathrm{kg})$, and an aspiration site was prepared at the iliac bone crest. By using a pediatric bone marrow aspiration needle, $5-8 \mathrm{ml}$ of bone marrow were aspirated into a syringe containing heparin (6,000 units). Syringes containing the bone marrow aspirate were sent to the GMP facility for processing, expansion and cryopreservation of MSC, following the procedures indicated below.

*Corresponding author: Jose J. Minguell, PhD, TCA Cellular Therapy, LLC. Covington, LA 70433 USA, Tel: 985-867-4860; Fax: 985-867-8259; E-mail: drminguell@tcaway.com

Received May 31, 2011; Accepted June 28, 2011; Published July 13, 2011

Citation: Minguell JJ, Pereira A, Bartholomew P and Lasala GP (2011) The Intrathecal Infusion of Mesenchymal Stem Cells into Healthy Rabbits is Safe and Devoid of Neurological or Clinical Complications. J Stem Cell Res Ther 2:104. doi:10.4172/2157-7633.1000104

Copyright: @ 2011 Minguell JJ, et al. This is an open-access article distributed under the terms of the Creative Commons Attribution License, which permits unrestricted use, distribution, and reproduction in any medium, provided the original author and source are credited. 
Citation: Minguell JJ, Pereira A, Bartholomew P and Lasala GP (2011) The Intrathecal Infusion of Mesenchymal Stem Cells into Healthy Rabbits is Safe and Devoid of Neurological or Clinical Complications. J Stem Cell Res Ther 2:104. doi:10.4172/2157-7633.1000104

Page 2 of 5

After aspiration, animals were taken to their cages and had free access to water and food. Rectal temperature was monitored during the next 2 days. Three days after bone marrow aspiration, animals were sacrificed by a lethal injection of pentobarbital $(200 \mathrm{mg} / \mathrm{kg})$.

\section{MSC expansion}

For MSC isolation and expansion, described procedures [22,23] were followed with minor modifications. Briefly, bone marrow aspirates were diluted with Dulbecco's Phosphate Buffered Saline (DPBS, Sigma Aldrich, St Louis, Mo, USA), and processed by gradient density separation (Histopaque-1077; Sigma Aldrich, St Louis, Mo, USA). The resulting fraction of mononuclear cells was suspended in a-MEM (Invitrogen, Carlsbad, CA, USA) containing $10 \%$ fetal bovine serum (Hyclone, Logan, UT, USA), seeded in $25 \mathrm{cc}$ culture flasks $\left(1 \times 10^{6} \mathrm{MNC} / \mathrm{cm}^{2}\right)$ and incubated $\left(5 \% \mathrm{CO}_{2}, 37^{\circ} \mathrm{C}\right)$ for 9 days. Cells in the developing adherent layer (MSC) were expanded by 3 successive passages. Culture medium was changed every 3 days. At the end of the expansion process, resulting MSC cells were prepared for cryopreservation and storage.

The day before cell infusion, frozen MSC were thawed, resuspended carefully in culture medium and subjected to a short incubation period $\left(24 \mathrm{hrs}, 37^{\circ} \mathrm{C}, 5 \% \mathrm{CO}_{2}\right)$ to remove cell aggregates and excess of DMSO. Resulting cells were resuspended in infusion medium (IM, DPBS containing $0.05 \%$ donor rabbit serum) and filtered (BD Falcon Cell Strainer, Nylon Mesh 100- $\mu \mathrm{m}$ ). Aliquots of the cell product were taken to assess cell number, viability (Trypan blue exclusion), endotoxin content (Limulus Amebocyte Lysate assay), microbiological condition (Fluid Thioglycollate Medium and Gram's stain) and for immunophenotype characterization [23].

\section{Cell infusion}

For intrathecal infusion, proper aliquots of the cell product were taken and resuspended in IM. A low $\left(0.3 \times 10^{6} \mathrm{MSC} / \mathrm{kg}\right)$ and a high cell dose $\left(0.6 \times 10^{6} \mathrm{MSC} / \mathrm{kg}\right)$ product was prepared and transferred to $1 \mathrm{cc}$ syringes. When translated to a clinical setting, the above doses will be comparable to the infusion of $0.1 \times 10^{6} / \mathrm{kg}$ to $2.5 \times 10^{6}$

MSC $/ \mathrm{kg}$, which is similar to the range of MSC utilized or proposed in clinical studies [21, 24-26].

For infusion, animals were anesthetized (IV sodium pentobarbital, $25 \mathrm{mg} / \mathrm{kg}$ ), placed on the operating surface with back in a flexed position and the intervertebral space (between L6 and L7) prepared. A spinal needle ( $25 \mathrm{GA}, 2.00 \mathrm{in} ; 0.50 \times 51 \mathrm{~mm}$ ) was inserted into the canal space and the precise position of the catheter was confirmed by cautious aspiration of a small volume $(0.2 \mathrm{cc})$ of cerebrospinal fluid. The cell products or the placebo solution (IM, no cells) were injected into the spinal fluid during a period of 1 minute. After removing the needle, the animals were placed head up for 30 minutes and then returned to their cages.

\section{Neurological and behavioral follow-up}

In anticipation that MSC infusion may trigger focal or diffuse changes (cortex, subcortex and/or spinal cord), animals were routinely inspected (days 3, 7, 14, 21 and 34) for the onset of distinctive signals , which in the rabbit have been associated with the development of
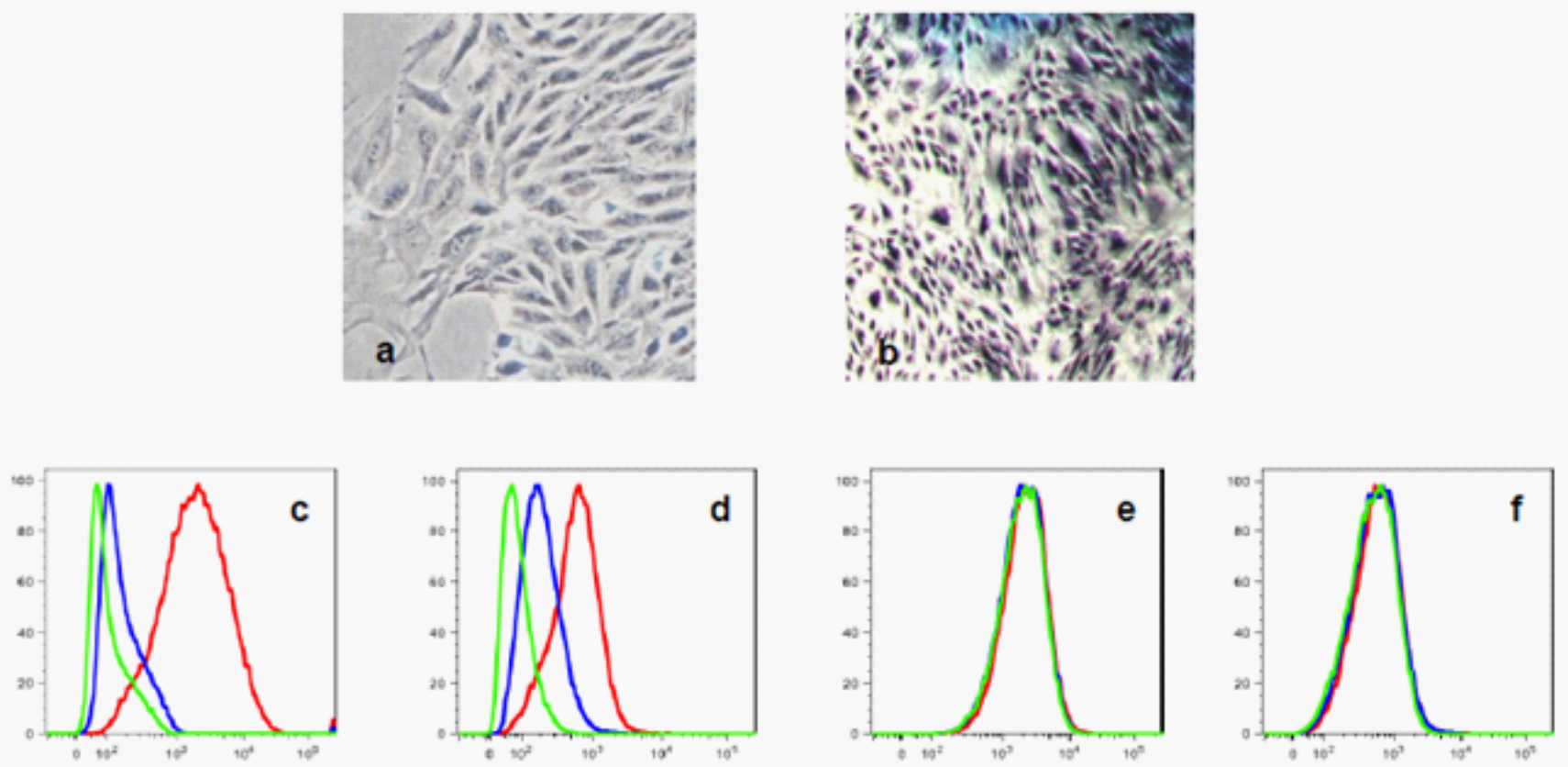

Figure 1: Characteristics of ex vivo expanded rabbit MSC.

Growing MSC develop as a monolayer of semi- confluent cells (a) which becomes confluent after 14-16 days in culture (b).

After releasing confluent MSC from the tissue culture flasks, a partial immunophenotype was assessed by Flow Cytometry. Histograms show: c) CD44 (90\%); d) $\beta 1$ Integrin (85\%); e) CD34 (0\%); f) CD45 (0\%)

Values in parenthesis indicate the percentage of expression of each antigen. Lines in the histogram correspond to autofluorescence (green), secondary antibody (blue) and primary antibody (red). 
Citation: Minguell JJ, Pereira A, Bartholomew P and Lasala GP (2011) The Intrathecal Infusion of Mesenchymal Stem Cells into Healthy Rabbits is Safe and Devoid of Neurological or Clinical Complications. J Stem Cell Res Ther 2:104. doi:10.4172/2157-7633.1000104

Page 3 of 5

Nystagmus (non-controlled eye movement and/or asymmetry of pupils) $[27,28]$, Myoclonous (involuntary twitching of one or a group of muscles) [29] and/or Hydrocephalous (eyes with 'setting-sun' appearance and/or abnormal sounds after fingertips on the skull) [30].

In turn, behavioral evaluations were done including changes in feeding (eating, drinking or coprophagy) and spontaneous (conduct inside the cage) manners [31]. Scores assigned to individual items were adjusted to yield a final score of 3 and 4 points for normal feeding (FB) and spontaneous (SB) behavior, respectively. Any increase over these scores was considered as abnormal.

\section{Histological studies}

After sacrifice, the whole spinal cord and brain of each animal were dissected and grossly examined for evidence of morphologic abnormalities. The tissue was placed in 10 percent neutral buffered formalin and fixed for greater than 48 hours. Serial sections of forebrain, midbrain, hindbrain, brainstem, cerebellum and spinal cord (cervical, thoracic and lumbar) were cut, processed and embedded in paraffin. Sections were cut (at 3-4 $\mu$ ), stained with hematoxylin-eosin and examined by a pathologist who was unaware of the animal group and of possible neurologic outcomes. The sections were examined for evidence of necrosis, inflammation, neoplasia and architectural distortion and atrophy. Since, there is abundant information describing MSC survival and migration within the CNS $[10,11]$, sections were not elsewise examined for engraftment of MSC.

\section{Results}

\section{Characteristics of rabbit mesenchymal stem cells}

Bone marrow-derived MSC grow as a population of plasticadherent large fibroblast-like cells $(20 \mu$ average diameter) (Figure 1a) which becomes confluent at a cell density of $7-10 \times 10^{3} / \mathrm{cm}^{2}$ (Figure $1 \mathrm{~b}$ ). Rabbit MSC express antigens CD44 (HCAM or Pgp1, Figure 1c) and CD29 (integrin $\beta 1$, Figure 1d), but do not express the myeloid antigens CD34 and CD45 (Figure 1e and f) [23]. Cells were cryopreserved, stored and thawed without compromising their cellular characteristics.

\section{Clinical assessment after infusion}

Rectal temperature in all animals was found to be within normal ranges for healthy rabbits $\left(38.3^{\circ} \mathrm{C}-39.4^{\circ} \mathrm{C}\right)$ during the entire evaluation period. Similarly, hematological values $(\mathrm{CBC})$ were within normal ranges, as reported for rabbits kept under laboratory conditions [32].
Throughout the time course of this study (34 days) and irrespective of the type of infusion received (low or high cell dose or placebo), body weight increased in all animals. The average increase in body weight during the study period was $25 \%$, which is within the reported frequency distribution of weight for young New Zealand white rabbits [33].

\section{Neurologic assessment after infusion}

After intrathecal infusion, animals were subjected to neurological evaluation at baseline and once a week. Results in Table 1 and 2 shows that during the entire period of evaluation and irrespective of the type of infusion received, clinical signs for nystagmus, myoclonus or hydrocephalus were not detected.

\section{Feeding and spontaneous behavior assessment}

The procedures associated with the administration of the cell or placebo product, brought forth changes $($ day +3$)$ in the Feeding $(\mathrm{FB})$ and Spontaneous (SB) behavior scores of all animals. These abnormal scores demonstrated to be transient in nature, since by day +7 normal behavior scores were detected in nearly all animals (Table 1 and 2).

\section{Histological assessment}

Serial sections of forebrain, midbrain, hindbrain, cerebellum and of each level of spinal cord of each animal were examined and showed no evidence of inflammation, necrosis, atrophy or neoplasia. There was no evidence of any architectural distortion. Representative photographs of sections are shown in (Figure 2).

\section{Discussion}

Despite there is an abundance of information concerning the infusion of mesenchymal stem cells to small animals (murine models of neurological diseases), scarce information is available about the safety and feasibility of the infusion of MSC to large animals. Accordingly, this study was designed to assess whether the intrathecal infusion of MSC into healthy rabbits was procedurally practicable, safe and devoid of side effects. Intrathecal infusion by lumbar puncture is considered as a unique technique for minimally invasive cell transplantation [12]. In addition, the infused cells mediated by cerebrospinal fluid circulation [11], are transported to the damaged tissue in the spinal cord and/or brain.

The results obtained demonstrated that: a) the procedure for the

\begin{tabular}{|c|c|c|c|c|c|c|c|c|c|}
\hline \multirow{3}{*}{\begin{tabular}{|c|} 
Infusion* \\
placebo (4)
\end{tabular}} & \multicolumn{3}{|c|}{ Day 0 (baseline) } & \multicolumn{3}{|c|}{ Day +3} & \multicolumn{3}{|c|}{ Day +7} \\
\hline & \multicolumn{2}{|c|}{ mean score $^{\mathrm{FB}}$} & \multirow{2}{*}{$\begin{array}{c}\text { N/M/H } \\
\text { no }\end{array}$} & \multicolumn{2}{|c|}{${ }_{\text {mean score }}^{\text {FB }}$} & \multirow{2}{*}{$\begin{array}{c}\text { N/M/H } \\
\text { no }\end{array}$} & \multicolumn{2}{|c|}{ mean score $^{\mathrm{FB}}$} & \multirow{2}{*}{$\begin{array}{c}\mathrm{N} / \mathrm{M} / \mathrm{H} \\
\text { no }\end{array}$} \\
\hline & 3.0 & 4.0 & & 5.3 & 8.0 & & 3.3 & 5.5 & \\
\hline low cells (4) & 3.0 & 4.0 & no & 5.0 & 8.0 & no & 3.0 & 5.5 & no \\
\hline high cells (4) & 3.0 & 4.0 & no & 4.8 & 7.5 & no & 3.0 & 5.0 & no \\
\hline
\end{tabular}

*: number of animals; FB: Feeding Behavior; SB: Spontaneous behavior; N/M/H: evidence of signs

for N: Nystagmus; M: Myoclonus and H: Hydrocephalus, as indicated in Materials and Methods.

Table 1: Short-term evaluation of clinical and neurological symptoms after intrathecal or placebo infusion of MSC.

\begin{tabular}{|c|c|c|c|c|c|c|c|c|c|c|c|c|}
\hline \multirow{3}{*}{\begin{tabular}{|c|} 
Infusion* \\
placebo (3)
\end{tabular}} & \multicolumn{3}{|c|}{ Day +7 } & \multicolumn{3}{|c|}{ Day +14 } & \multicolumn{3}{|c|}{ Day +21 } & \multicolumn{3}{|c|}{ Day +34 } \\
\hline & \multicolumn{2}{|c|}{$\begin{array}{l}\text { FB SB } \\
\text { mean score }\end{array}$} & \multirow{2}{*}{$\begin{array}{c}\text { N/M/H } \\
\text { no }\end{array}$} & \multicolumn{2}{|c|}{$\begin{array}{l}\text { FB SB } \\
\text { mean score }\end{array}$} & \multirow{2}{*}{$\begin{array}{c}\text { N/M/H } \\
\text { no }\end{array}$} & \multicolumn{2}{|c|}{$\begin{array}{l}\text { FB SB } \\
\text { mean score }\end{array}$} & \multirow{2}{*}{$\begin{array}{c}\text { N/M/H } \\
\text { no }\end{array}$} & \multicolumn{2}{|c|}{$\begin{array}{c}\text { FB SB } \\
\text { mean score }\end{array}$} & \multirow{2}{*}{$\begin{array}{c}\text { N/M/H } \\
\text { no }\end{array}$} \\
\hline & 3.3 & 5.5 & & 3.3 & 4.0 & & 3 & 4 & & 3 & 4 & \\
\hline low cells (4) & 3.0 & 5.5 & no & 3.0 & 4.0 & no & 3 & 4 & no & 3 & 4 & no \\
\hline high cells (4) & 3.0 & 5.0 & no & 3.0 & 4.0 & no & 3 & 4 & no & 3 & 4 & no \\
\hline
\end{tabular}

For abbreviations, see Table 1

Table 2: Long-term evaluation of clinical and neurological symptoms after intrathecal or placebo infusion of MSC. 
Citation: Minguell JJ, Pereira A, Bartholomew P and Lasala GP (2011) The Intrathecal Infusion of Mesenchymal Stem Cells into Healthy Rabbits is Safe and Devoid of Neurological or Clinical Complications. J Stem Cell Res Ther 2:104. doi:10.4172/2157-7633.1000104
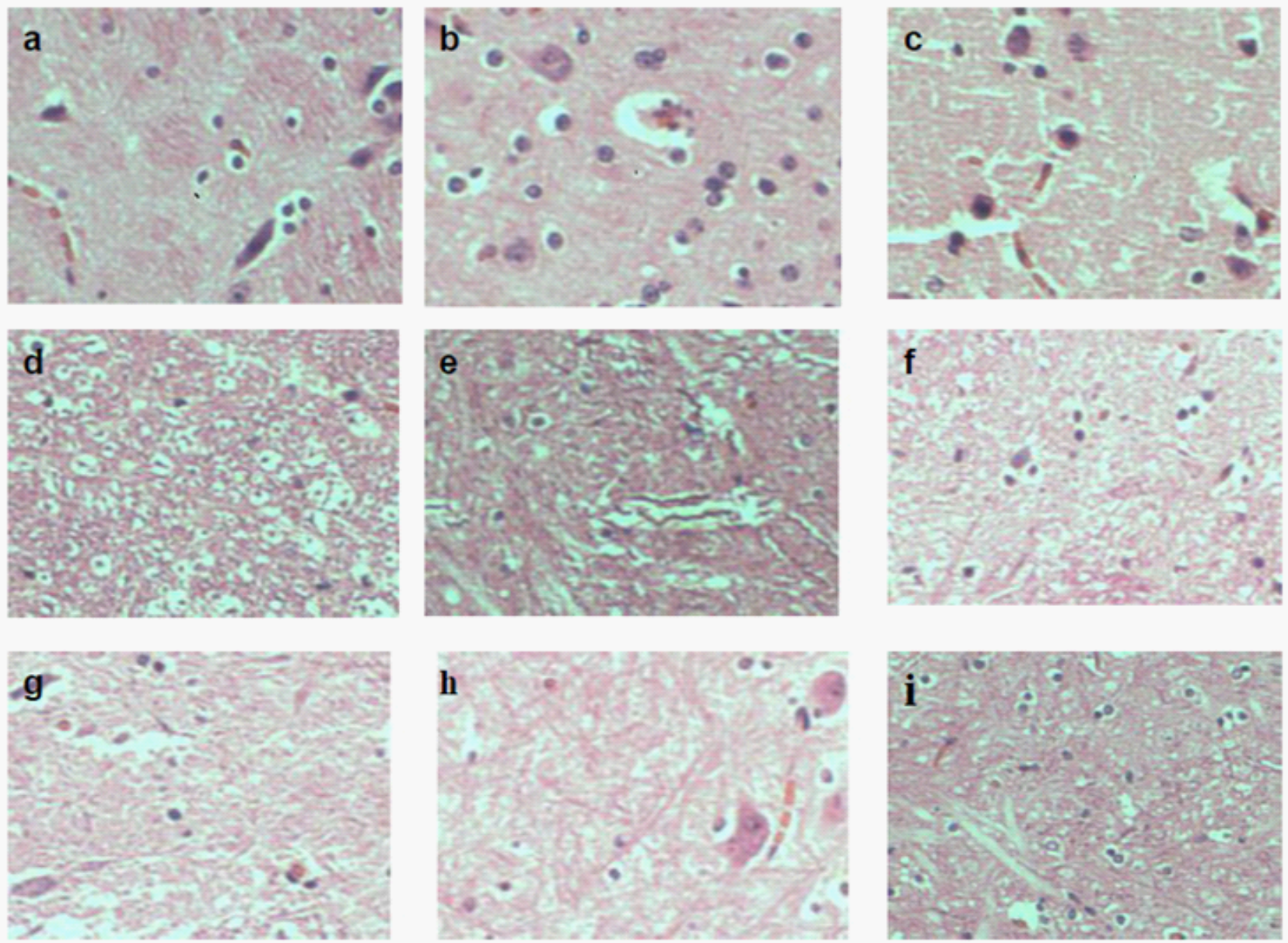

Figure 2: Histological evaluation of tissue sections.

Hemotoxylin and eosin-stained sections prepared from a rabbit infused with a high dose of MSC. Pictures correspond to: hindbrain (a); brainstem (b); cerebellum (c); upper cervical cord (d); mid cervical cord (e) and serial sections of lumbar sacral cord (f-i).

intrathecal infusion by lumbar puncture of MSC was uncomplicated. After the forward movement of the spinal needle into the spinal canal (L7) and aspiration of a small volume of CSF, the cell product was delivered into the spinal fluid in less than 2 minutes, b) after infusion, changes in the Feeding (FB) and Spontaneous (SB) behavior of the animals were detected; however effects were transient and vanished in almost all animals by day 7 after infusion. Since these transitory modifications in animal demeanor were equally detected in cell-and placebo-infused animals, we speculate that their origin was mainly associated with lumbar puncture maneuvers rather than to infusion of cells into the spinal canal, c) additional strength to the notion that the infusion of MSC by lumbar puncture is not harmful, was given by the observation that the increase in body weight during the evaluation period was similar in control and cell-infused animals. This observation is important since preclinical studies have shown that delayed body weight development is secondary to vascular or neurological damage [34], d) no signs of neuropathological findings (suggestive of brain lesions, focal CNS damage and/or obstruction of CSF flow) [35], were detected during the follow up period (Table 2, N/M/H column) both in treated and control animals, and finally, e) the histopathological examination confirmed in the tissue specimens prepared from all animals, normal histology and no evidence of increased inflammation or cellular atypia. Thus, our study demonstrated that the intrathecal infusion of MSC can be readily performed under safe and feasible conditions without inducing neurological and histological changes.

As mentioned in the Introduction, a main issue in cell therapy is to identify not only a proper and safe route for cell infusion, but the assurance that security persists with time and is not dependent on the number of cells infused.

As this was be case in this study, the translation of these findings to a clinical setting put forward the acquiescence that nearly nine months after MSC infusion, patient's safety will persists. Alike time is consider long enough to prove security in a clinical setting [2].

Consequently, our results showing that intrathecal infusion of MSC is safe and feasible, in addition to data demonstrating MSC survival/ migration within the CNS $[6,13]$ and effectiveness in neurological recovery $[6,15]$, epitomize a weighty foundation for their use in the treatment of neurological patients.

\section{Acknowledgements}

We thank Denise Gonsior for valuable technical assistance, Ana Maria 
Citation: Minguell JJ, Pereira A, Bartholomew P and Lasala GP (2011) The Intrathecal Infusion of Mesenchymal Stem Cells into Healthy Rabbits is Safe and Devoid of Neurological or Clinical Complications. J Stem Cell Res Ther 2:104. doi:10.4172/2157-7633.1000104

Page 5 of 5

Madariaga, DVM, Universidad de Alicante, Spain, Bapi Pahar, Flow Cytometry Facility, Tulane National Primate Research Center, LA, USA, for insightfu discussions and Janet Jones, PhD for feedback during the preparation of the manuscript.

Funding for this study was provided by TCA Cellular Therapy, LLC.

The authors declare no conflict of interest.

\section{References}

1. Ankeny DP, McTigue DM, Jakeman LB (2004) Bone marrow transplants provide tissue protection and directional guidance for axons after contusive spinal cord injury in rats. Exp Neurol 190: 17-31.

2. Hackam DG (2007) Translating animal research into clinical benefit. BMJ 334 163-164.

3. Kim SU, de Vellis J (2009) Stem cell-based cell therapy in neurological diseases: a review. J Neurosci Res 87: 2183-2200.

4. Minguell JJ, Erices A, Conget P (2001) Mesenchymal stem cells. Exp Biol Med 226: 507-520.

5. Minguell JJ, Fierro FA, Epuñan MJ, Erices AA, Sierralta WD (2005) Nonstimulated human uncommitted mesenchymal stem cells express cell markers of mesenchymal and neural lineages. Stem Cells Dev 14: 408-414.

6. Neuhuber B, Himes TB, Shumsky JS, Gallo G, Fischer I (2005) Axon growth and recovery of function supported by human bone marrow stromal cells in the injured spinal cord exhibit donor variations. Brain Res 1035: 73-85.

7. Torrente Y, Polli E (2008) Mesenchymal stem cell transplantation for neurodegenerative diseases. Cell Transplant 17: 1103-1113.

8. Wright KT, Masri WE, Osman A, Roberts S, Trivedi J, et al. (2008) The cell culture expansion of bone marrow stromal cells from humans with spinal cord injury: implications for future cell transplantation therapy. Spinal Cord 46: 811817.

9. Rivera FJ, Sierralta WD, Minguell JJ, Aigner L (2006) Adult hippocampus derived soluble factors induce a neuronal-like phenotype in mesenchymal stem cells. Neurosci Lett 406: 49-54.

10. Deng J, Petersenb BE, Steindlerb DA, Jorgensenb ML, Laywella ED (2006) Mesenchymal Stem Cells Spontaneously Express Neural Proteins in Culture and Are Neurogenic after Transplantation. Stem Cells 24: 1054-1064.

11. Satake K, Lou J, Lenke LG (2004) Migration of mesenchymal stem cells through cerebrospinal fluid into injured spinal cord tissue. Spine 29: 1971-1979.

12. Bakshi A, Barshinger AL, Swanger SA, Madhavani V, Shumsky JS, et al. (2006) Lumbar puncture delivery of bone marrow stromal cells in spinal cord contusion: a novel method for minimally invasive cell transplantation. J Neurotrauma 23: 55-65

13. Zhao CP, Zhang C, Zhou SN, Xie YM, Wang YH, et al. (2007) Human mesenchymal stromal cells ameliorate the phenotype of SOD1-G93A ALS mice. Cytotherapy 9: 414-426.

14. Ding DC, Shyu WC, Chiang MF, Lin SZ, Chang YC, et al. (2007) Enhancement of neuroplasticity through upregulation of beta1-integrin in human umbilical cord-derived stromal cell implanted stroke model. Neurobiol Dis 27: 339-353.

15. Wang F, Yasuhara T, Shingo T, Kameda M, Tajiri N, et al. (2010) Intravenous administration of mesenchymal stem cells exerts therapeutic effects on parkinsonian model of rats: focusing on neuroprotective effects of stromal cellderived factor-1alpha. BMC Neurosci 11: 52

16. Zhao LR, Duan WM, Reyes M, Keene CD, Verfaillie CM, et al. (2002) Human bone marrow stem cells exhibit neural phenotypes and ameliorate neurological deficits after grafting into the ischemic brain of rats. Exp Neurol 174: 11-20.

17. Kang SK, Lee DH, Bae YC, Kim HK, Baik SY, et al. (2003) Improvement of neurological deficits by intracerebral transplantation of human adipose tissue -derived stromal cells after cerebral ischemia in rats. Exp Neurol 183: 355-366.

18. Vaquero J, Zurita M, Oya S, Santos M (2006) Cell therapy using bone marrow stromal cells in chronic paraplegic rats: systemic or local administration? Neurosci Lett 398: 129-134.
19. Morita E, Watanabe $Y$, Ishimoto M, Nakano T, Kitayama M, et al. (2008) A novel cell transplantation protocol and its application to an ALS mouse model. Exp Neurol 213: 431-438.

20. Neuhuber B, Barshinger AL, Paul C, Shumsky JS, Mitsui T, et al. (2008) Stem cell delivery by lumbar puncture as a therapeutic alternative to direct injection into injured spinal cord. J Neurosurg Spine 9: 390-399.

21. Clinical Trial (2010) www.clinicaltrails.gov Identifier NCT01082653.

22. Conget PA, Minguell JJ (1999) Phenotypical and functional properties of human bone marrow mesenchymal progenitor cells. J Cell Physiol 181: 67-73.

23. Lapi S, Nocchi F, Lamanna R, Passeri S, Lorio M, et al. (2008) Different media and supplements modulate the clonogenic and expansion properties of rabbit bone marrow mesenchymal stem cells. BMC Res Notes 1: 53.

24. Callera F, do Nascimento RX (2006) Delivery of autologous bone marrow precursor cells into the spinal cord via lumbar puncture technique in patients with spinal cord injury: a preliminary safety study. Exp Hematol 34: 130-131.

25. Mazzini L, Mareschi K, Ferrero I, Vassallo E, Oliveri G, et al. (2006) Autologous mesenchymal stem cells: clinical applications in amyotrophic lateral sclerosis. Neurol Res 28: 523-526.

26. Yoon SH, Shim YS, Park YH, Chung JK, Nam JH, et al. (2007) Complete spina cord injury treatment using autologous bone marrow cell transplantation and bone marrow stimulation with granulocyte macrophage-colony stimulating factor: Phase I/II clinical trial. Stem Cells 8: 2066-2073.

27. Nakanishi K (1979) Nystagmic responses of hippocampal origin in norma rabbits. Auris Nasus Larynx 6: 47-54.

28. Barmack NH, Pettorossi VE (1988) The induction and compensation of asymmetric eye movements following unilateral blockage of a horizontal semicircular canal in the rabbit. J Neurosci 8: 2836-2843.

29. Elbasiouny SM, Moroz D, Bakr MM, Mushahwar VK (2010) Management of spasticity after spinal cord injury: current techniques and future directions. Neurorehabil Neural Repair 24: 23-33.

30. Gopinath G, Bhatia R, Gopinath PG (1979) Ultrastructural observations in experimental hydrocephalus in the rabbit. J Neurol Sci 43: 333-433.

31. Krohn TC, Ritskes-Hoitinga J, Svendsen P (1999) The effects of feeding and housing on the behavior of the laboratory rabbit. Lab Anim 33: 101-107.

32. Hewitt CD, Innes DJ, Savory J, Wills MR (1989) Normal biochemical and hematological values in New Zealand white rabbits. Clin Chem 35: 1777-1779.

33. Rao DR, Sunki GR, Johnson WM, Chen CP (1977) Postnatal Growth of New Zealand White Rabbit (Oryctolagus Cuniculus). J Anim Sci. 44: 1021-1025.

34. Dittmar M, Spruss T, Schuierer G, Horn M (2003) External carotid artery territory ischemia impairs outcome in the endovascular filament model of middle cerebral artery occlusion in rats. Stroke 34: 2252-2257.

35. He BP, Strong MJ (2000) A morphological analysis of the motor neuron degeneration and microglial reaction in acute and chronic in vivo aluminum chloride neurotoxicity. J Chem Neuroanat 17: 207-215. 